\title{
Biochemical Phenotyping of Soybean [Glycine max (L.) Merill] Genotypes to Establish the Role of Lipid Peroxidation and Antioxidant Enzymes in Seed Longevity
}

\author{
Jagadish Hosamani • M. Dadlani • I. M. Santha • \\ M. B. Arun Kumar · Sherry Rachel Jacob
}

Received: 19 October 2012/Accepted: 2 April 2013/Published online: 10 May 2013

(C) NAAS (National Academy of Agricultural Sciences) 2013

\begin{abstract}
Thirty-three soybean [Glycine max (L.) Merill] genotypes, comprising 14 black-seeded and 19 yellow-seeded ones, were selected on the basis of their reported storability for the biochemical phenotyping to establish the role of lipid peroxidation and antioxidant enzymes in seed longevity. The present study revealed clear genotypic variability with respect to storability among different soybean genotypes. Good-storer genotypes with lower electrolyte leakage were characterized by smaller seed size with black testa color. The level of volatile aldehydes released and lipoxygenase II enzyme activity were higher in the yellow-seeded genotypes than in the black-seeded genotypes, though it increased in all during ageing. A sharp increase in the release of volatile aldehydes and lipoxygenase II activity, concomitant with the reduction in germination under uncontrolled laboratory conditions of storage indicated the role of lipid peroxidation in seed longevity behavior $\left(r=-0.6638^{* *}\right.$ and $r=-0.7639^{* *}$, respectively). No significant difference was noted in the mean hydroperoxide lyase activity of black and yellow-seeded genotypes. However, maintenance of high hydroperoxide lyase activity during storage resulted in higher release of volatile aldehydes and poor storability of seeds. Significantly higher antioxidant enzyme activity was recorded in the black-seeded genotypes than in the yellow-seeded ones, though there was a reduction in hydroperoxide lyase activity during storage in all the genotypes. The viability of black-seeded genotypes after storage for 1 year was better than the yellow-seeded genotypes.
\end{abstract}

Keywords Soybean $\cdot$ Lipid peroxidation $\cdot$ Antioxidant enzymes $\cdot$ Germination

J. Hosamani · M. B. Arun Kumar

Division of Seed Science and Technology, Indian Agricultural

Research Institute, New Delhi 110012, India

e-mail: jagiari@gmail.com

\section{Dadlani ( ()}

Indian Agricultural Research Institute, New Delhi 110012, India

e-mail: jd_research@iari.res.in

\section{M. Santha}

Division of Biochemistry, Indian Agricultural Research Institute, New Delhi 110012, India

S. R. Jacob

National Bureau of Plant Genetic Resources, Indian Agricultural Research Institute, New Delhi 110012, India

\section{Introduction}

Soybean [Glycine max (L.) Merill] has assumed an important position in India's oilseed cultivation scenario, due to its high productivity and vital contribution towards maintaining soil fertility.

Though the area under soybean has grown from 6.4 mha in 2000 to more than $9 \mathrm{mha}$ in 2010, the maintenance of seed quality remains a matter of concern in soybean cultivation.

Seeds attain maximum potential for germination and vigor at physiological maturity, wherein a non-dormant seed would, theoretically, be capable of $100 \%$ germination. Subsequently, the seed quality deteriorates fast, particularly under warm and humid climatic conditions, as prevalent in India. Soybean seed germination is often reduced below the recommended standards (70\% 
Table 1 Seed coat color, germination percentage, and 100 seed weight of soybean genotypes before and after 12 months of storage

\begin{tabular}{|c|c|c|c|c|c|c|}
\hline \multirow[t]{2}{*}{ S. No. } & \multirow[t]{2}{*}{ Genotypes } & \multirow[t]{2}{*}{ Seed coat color } & \multicolumn{2}{|l|}{ Before storage } & \multicolumn{2}{|l|}{ After storage } \\
\hline & & & Germination \% & 100 seed weight $(\mathrm{g})$ & Germination \% & 100 seed weight $(\mathrm{g})$ \\
\hline & Good storers & & & & & \\
\hline 1 & AMSS-34 & Black & $98(83.44)^{\mathrm{bac}}$ & 6.238 & $88(69.73)^{\mathrm{dc}}$ & 7.332 \\
\hline 2 & DS-74 & Black & $99(85.37)^{\mathrm{ba}}$ & 6.49 & $90(71.62)^{\mathrm{bdc}}$ & 7.454 \\
\hline 3 & DS-MM-64 & Black & $99(85.37)^{\mathrm{ba}}$ & 6.887 & $94(75.95)^{\mathrm{ba}}$ & 7.372 \\
\hline 4 & G-2253 & Black & $97(81.95)^{\mathrm{bac}}$ & 6.576 & $90(71.62)^{\mathrm{bdc}}$ & 6.887 \\
\hline 5 & G-2265 & Black & $98(81.87)^{\text {bac }}$ & 6.661 & $88(69.90)^{\mathrm{dc}}$ & 6.89 \\
\hline 6 & G-2601 & Black & $99(85.37)^{\mathrm{ba}}$ & 6.479 & $90(71.62)^{\mathrm{bdc}}$ & 6.945 \\
\hline 7 & G-2603 & Black & $98(81.87)^{\text {bac }}$ & 6.533 & $96(78.46)^{\mathrm{a}}$ & 7.885 \\
\hline 8 & G-2614 & Black & $98(81.87)^{\text {bac }}$ & 6.858 & $90(71.62)^{\mathrm{bdc}}$ & 7.346 \\
\hline 9 & G-2651 & Black & $99(85.37)^{\mathrm{ba}}$ & 6.776 & $96(78.46)^{\mathrm{a}}$ & 7.487 \\
\hline 10 & M-253 & Black & $100(90.00)^{\mathrm{a}}$ & 6.773 & $88(69.73)^{\mathrm{dc}}$ & 7.26 \\
\hline 11 & M-1090 & Black & $99(85.37)^{\mathrm{ba}}$ & 7.608 & $86(68.06)^{\mathrm{d}}$ & 8.459 \\
\hline 12 & M-11913 & Black & $99(85.37)^{\mathrm{ba}}$ & 6.773 & $86(68.06)^{\mathrm{d}}$ & 7.416 \\
\hline 13 & TG X 444-422 & Black & $99(85.37)^{\mathrm{ba}}$ & 6.959 & $92(73.57)^{\text {bac }}$ & 7.432 \\
\hline \multirow[t]{3}{*}{14} & P-761 & Black & $97(80.12)^{\mathrm{bc}}$ & 7.419 & $84(66.42)^{\mathrm{ed}}$ & 8.062 \\
\hline & Mean & & 98.5 (84.19) & 6.788 & 89.85 (71.77) & 7.445 \\
\hline & Poor storers & & & & & \\
\hline 15 & P-218 & Yellow & $96(78.46)^{\mathrm{bc}}$ & 7.123 & $74(59.35)^{\mathrm{gf}}$ & 7.651 \\
\hline 16 & P-222 & Yellow & $97(80.12)^{\mathrm{bc}}$ & 7.749 & $74(59.35)^{g f}$ & 8.33 \\
\hline 17 & P-241 & Yellow & $99(85.37)^{\mathrm{ba}}$ & 7.782 & $78(62.04)^{\mathrm{ef}}$ & 8.309 \\
\hline 18 & $\mathrm{P}-250$ & Yellow & $98(81.87)^{\text {bac }}$ & 9.036 & $70(56.79)^{\text {gifh }}$ & 9.754 \\
\hline 19 & P-732 & Yellow & $99(85.37)^{\mathrm{ba}}$ & 7.138 & $66(54.33)^{\mathrm{gijh}}$ & 9.158 \\
\hline 20 & P-871 & Yellow & $97(80.12)^{\mathrm{bc}}$ & 9.399 & $64(53.15)^{\mathrm{ijh}}$ & 11.11 \\
\hline 21 & P-876 & Yellow & $98(81.87)^{\text {bac }}$ & 7.401 & $72(58.09)^{\mathrm{gfh}}$ & 8.212 \\
\hline 22 & P-884 & Yellow & $97(80.12)^{\mathrm{bc}}$ & 10.61 & $74(59.35)^{\mathrm{gf}}$ & 11.45 \\
\hline 23 & P-898 & Yellow & $97(80.12)^{\mathrm{bc}}$ & 7.587 & $74(59.35)^{\mathrm{gf}}$ & 8.099 \\
\hline 24 & PK-262 & Yellow & $94(75.95)^{\mathrm{bc}}$ & 10.55 & $62(51.94)^{\mathrm{ij}}$ & 11.72 \\
\hline 25 & PK-416 & Yellow & $95(77.12)^{\mathrm{bc}}$ & 9.522 & $64(53.15)^{\mathrm{ijh}}$ & 10.13 \\
\hline 26 & PK-472 & Yellow & $94(75.82)^{\mathrm{bc}}$ & 10.82 & $60(50.78)^{\mathrm{j}}$ & 12.22 \\
\hline 27 & TAMS-38 & Yellow & $94(75.82)^{\mathrm{bc}}$ & 8.047 & $72(58.09)^{\mathrm{gfh}}$ & 8.946 \\
\hline 28 & EC-13969 & Yellow & $93(74.89)^{\mathrm{c}}$ & 7.321 & $78(62.04)^{\mathrm{ef}}$ & 8.661 \\
\hline 29 & EC-1023 & Yellow & $98(81.87)^{\text {bac }}$ & 7.736 & $78(62.04)^{\mathrm{ef}}$ & 8.272 \\
\hline 30 & EC-34141 & Yellow & $93(74.89)^{\mathrm{c}}$ & 11.2 & $66(54.33)^{\mathrm{gijh}}$ & 12.79 \\
\hline 31 & EC-93751 & Yellow & $96(78.46)^{\mathrm{bc}}$ & 7.188 & $78(62.04)^{\mathrm{ef}}$ & 7.605 \\
\hline 32 & EC-18761 & Yellow & $96(78.71)^{\mathrm{bc}}$ & 7.576 & $70(56.79)^{\text {gifh }}$ & 10.05 \\
\hline \multirow[t]{4}{*}{33} & MACS-681 & Yellow & $97(80.12)^{\mathrm{bc}}$ & 6.978 & $78(62.04)^{\mathrm{ef}}$ & 7.364 \\
\hline & Mean & & $96.21(79.32)$ & 8.463 & 71.15 (57.63) & 9.466 \\
\hline & MSD at $5 \%$ & & 9.833 & 0.5472 & 5.439 & 0.4124 \\
\hline & SE (d) & & 1.427 & 0.3336 & 1.057 & 0.2894 \\
\hline
\end{tabular}

Values in parentheses are arc sin transformed. Similar alphabets indicate non-significant differences between the values, following Tukey's studentized range (HSD) test

germination) within a single planting season, due to field weathering [6], mechanical damage, and physio-biochemical parameters [3]. However, large variations are reported for seed deterioration in soybean. Black-seeded landraces of tropical and subtropical regions such as T-49, Birsa-1 and Kalitur were found to have better storability than the yellow-seeded temperate varieties such as Clark-63, Lee and Bragg [10, 11].

Lipoxygenase (LOX) activities are reported to be associated positively with seed ageing in soybean [16]. High activity of LOX I, LOX II, and production of malondialdehyde and other volatile aldehydes were more in the bold 
and yellow-seeded poor-storer varieties than the black and small-seeded good-storer varieties [3]. This peroxidation process results in the accumulation of active oxygen species (AOS) or free radicals, which has been reported to cause cell injury and disturbances in cellular integrity, resulting in rapid loss of germination [17]. Such seed lots have been shown to have high electrolyte leakage, whereas seeds with high vigor and hence, good storability, have low electrolyte leakage [8].

The mechanism by which the cell protects its integrity is by mopping-up (the excessive) free radicals by the activity of an active oxygen-scavenging system (AOSS), viz., superoxide dismutase (SOD), peroxidase (POX), and catalase (CAT). Activity of such enzymes lowers active oxygen/hydroxyl radical formation. Loss of seed viability is reported to be associated with a reduction in the activities of antioxidant enzymes [4, 10]. However, inconsistent results were reported with respect to the storage patterns and antioxidant activities in the fresh seeds of different genotypes.

The present study was undertaken during 2009-11 with the objective of biochemical phenotyping of soybean genotypes to establish the role of lipid peroxidation and antioxidant enzymes in seed longevity.

\section{Materials and Methods}

\section{Plant Materials}

Thirty-three soybean germplasm lines (14 black-seeded and 19 yellow-seeded) were collected from the Senior Soybean Breeder, Division of Genetics, IARI, New Delhi (Table 1). The genotypes were selected based on preliminary studies conducted by earlier workers $[3$, Dr. S. K. Lal, unpublished], wherein a general categorization of soybean genotypes into good, medium, and poor storers was carried out. The seeds were used after one cycle of multiplication, during the wet season (kharif), 2009 in the Research Farms of Division of Seed Science and Technology, IARI, New Delhi, so as to ensure uniformity in the physiological status of the seeds. Seeds were threshed and cleaned manually to avoid mechanical injuries. All postharvest operations were conducted manually, in order to minimize mechanical injuries. Uniform moisture content was ensured in all seed lots prior to the onset of the experiment by drying in silica gel.

\section{Seed Storage}

About $150 \mathrm{~g}$ of untreated fresh soybean seeds were packed in cloth bags (after drying the samples to an average seed moisture content of $7.8 \%$ ) and stored under uncontrolled conditions in the laboratory with an average relative humidity of $65 \pm 5 \%(\max 93 \%$ and $\min 14 \%)$ and temperature of $25 \pm 2{ }^{\circ} \mathrm{C}\left(\max 40^{\circ} \mathrm{C}\right.$ and $\left.\min 13{ }^{\circ} \mathrm{C}\right)$ up to 1 year. Samples were drawn at the start of the experiment and after 12 months of storage for evaluation of the following parameters.

\section{Germination Test}

Germination was tested at $25{ }^{\circ} \mathrm{C}$ in three replications of 100 seeds each, following the between-paper (BP) method [9]. The germinated seeds were evaluated as normal seedlings, abnormal seedlings, hard seeds, and dead seeds. The presented germination percentage values correspond to the mean percentage of normal seedlings. Values were recorded on the 8 th day of germination.

\section{Electrical Conductivity of Seed Leachate}

The extent of membrane permeability was measured as electrical conductance of seed leachate by following the standard procedure of Agrawal and Dadlani [2]. The results were expressed as $\mu \mathrm{S} / \mathrm{cm} / \mathrm{g}$ of seed fresh weight.

\section{Lipid Peroxidation Studies}

Production of volatile aldehydes was measured using MBTH test as per the procedure of Wilson and McDonald [20]. The aldehyde released was expressed as micrograms formaldehyde per gram of seed fresh weight. Lipoxygenase II (EC 1.13.11.13) enzyme activity was assayed as per the procedure described by Grossman and Zakut [7]. The results were expressed as $\mathrm{U} / \mathrm{min} / \mathrm{g}$ of seed fresh weight. One unit of LOX activity was defined as an increase in absorbance at $234 \mathrm{~nm} / \mathrm{min} / \mathrm{g}$ of seed fresh weight under assay conditions. Hydroperoxide lyase (EC 4.2.1.92) enzyme activity was assayed as per the procedure described by Vick [18]. The net enzyme rate was expressed as $\mu$ moles of NADH oxidized per min per gram of seed fresh weight.

\section{Antioxidant Enzyme Assays}

Superoxide dismutase (EC 1.15.11) activity was measured as per the procedure of Beauchamp and Fridovich [5]. The results were expressed as $\mathrm{U} / \mathrm{min} / \mathrm{g}$ of seed fresh weight. One unit of SOD activity was defined as the enzyme activity which inhibited the photo reduction of NBT to blue formazan by $50 \%$. Glutathione reductase (GR, EC 1.6.4.2) activity was determined as previously described by Mavis and Stellwagen [15], by following the rate of NADPH oxidation at $340 \mathrm{~nm}$. The results were expressed as $\mu$ moles of NADPH oxidized/min/g of seed fresh weight. Catalase 
(EC 1.11.1.6) activity was determined as per the methodology of Aebi [1]. The results were expressed as $\mu$ moles of $\mathrm{H}_{2} \mathrm{O}_{2}$ decomposed/min/g of seed fresh weight.

\section{Statistical Analysis}

The data was analyzed using SAS software package version 9.2, for calculation of minimum significant difference (MSD). All the replicated data was subjected to Tukey's studentized range (HSD) test.

\section{Results and Discussion}

The study involved biochemical evaluation of the storability trend in black- and yellow-seeded soybean genotypes through assessment of multiple parameters that are indicators of the lipid peroxidation and antioxidant mechanisms.

\section{0-Seed Weight}

The data recorded at the end of the storage period revealed a higher increase in 100-seed weight of yellow-seeded genotypes (8.463-9.466 g) than that of black-seeded genotypes (6.788-7.445) (Table 1). This indicated higher moisture absorption by the former, which is also reported to be a characteristic of the poor-storer genotypes [12, 14]. This difference in the moisture sorption between black- and yellow-seeded genotypes may be attributed to the inherent difference in their seed coat characteristics.

\section{Germination Percentage}

The initial germination percentage was above $90 \%$ for all genotypes (Table 1). However, after 12 months of uncontrolled laboratory storage $\left(25 \pm 2{ }^{\circ} \mathrm{C}\right.$ and $\left.65 \pm 5 \% \mathrm{RH}\right)$, the germination of the black-seeded soybean genotypes was reduced by $12.42 \%$, whereas in the yellow-seeded genotypes it reduced by $21.69 \%$. In case of black-seeded genotypes, the mean germination percentage recorded was $89.85 \%$, whereas in the yellow-seeded genotypes it was $71.15 \%$ (Table 1).

It was evident that there is genotypic variability with respect to storability among different soybean varieties and the black-seeded varieties in general showed better storability. This is in general confirmation of observations made by previous researchers' viz., Kueneman and Wein [11] and Kuchlan [10]. Henceforth, based on this germination data, the black-seeded genotypes have been referred to as good storers and the yellow-seeded genotypes have been referred as poor storers.

\section{Electrical Conductivity of Seed Leachate}

In case of freshly harvested seeds, good-storer genotypes have shown $13.31(\mu \mathrm{S} / \mathrm{cm} / \mathrm{g}$ seed) electrical leakage as compared to poor-storer genotypes 23.11 ( $\mu \mathrm{S} / \mathrm{cm} / \mathrm{g}$ seed). In case of ambient stored seeds, good-storer genotypes have shown $15.73(\mu \mathrm{S} / \mathrm{cm} / \mathrm{g}$ seed) electrical leakage as

Table 2 Variation in electrical conductivity (EC) of seed leachate among 33 soybean genotypes before and after 12 months of storage

\begin{tabular}{|c|c|c|c|}
\hline \multirow[t]{2}{*}{ S. No. } & \multirow[t]{2}{*}{ Genotypes } & \multicolumn{2}{|c|}{$\mathrm{EC}(\mu \mathrm{S} / \mathrm{cm} / \mathrm{g}$ seed $)$} \\
\hline & & Before storage & After storage \\
\hline & Good storers & & \\
\hline 1 & AMSS-34 & 11.04 & 14.68 \\
\hline 2 & DS-74 & 14.72 & 15.71 \\
\hline 3 & DS-MM-64 & 12.95 & 15.46 \\
\hline 4 & G-2253 & 14.13 & 14.17 \\
\hline 5 & G-2265 & 14.28 & 15.20 \\
\hline 6 & G-2601 & 11.48 & 14.42 \\
\hline 7 & G-2603 & 12.95 & 14.68 \\
\hline 8 & G-2614 & 14.13 & 14.68 \\
\hline 9 & G-2651 & 10.74 & 13.14 \\
\hline 10 & M-253 & 12.36 & 14.68 \\
\hline 11 & M-1090 & 15.16 & 18.55 \\
\hline 12 & M-11913 & 14.13 & 18.55 \\
\hline 13 & TG X 444-422 & 13.69 & 15.46 \\
\hline \multirow[t]{3}{*}{14} & P-761 & 14.57 & 20.87 \\
\hline & Mean & 13.31 & 15.73 \\
\hline & Poor storers & & \\
\hline 15 & P-218 & 16.34 & 20.09 \\
\hline 16 & $\mathrm{P}-222$ & 17.81 & 25.25 \\
\hline 17 & P-241 & 18.99 & 26.79 \\
\hline 18 & P-250 & 18.55 & 28.60 \\
\hline 19 & P-732 & 19.87 & 24.99 \\
\hline 20 & P-871 & 22.08 & 32.72 \\
\hline 21 & P-876 & 23.11 & 24.47 \\
\hline 22 & P-884 & 28.41 & 45.60 \\
\hline 23 & P-898 & 18.11 & 24.99 \\
\hline 24 & PK-262 & 31.06 & 45.34 \\
\hline 25 & PK-416 & 25.76 & 32.72 \\
\hline 26 & PK-472 & 35.33 & 41.48 \\
\hline 27 & TAMS-38 & 26.06 & 27.05 \\
\hline 28 & EC-13969 & 19.43 & 24.22 \\
\hline 29 & EC-1023 & 20.90 & 23.69 \\
\hline 30 & EC-34141 & 38.42 & 41.74 \\
\hline 31 & EC-93751 & 18.99 & 22.11 \\
\hline 32 & EC-18761 & 19.58 & 31.95 \\
\hline \multirow[t]{4}{*}{33} & MACS-681 & 20.31 & 23.70 \\
\hline & Mean & 23.11 & 29.86 \\
\hline & MSD at $5 \%$ & 1.396 & 3.139 \\
\hline & SE (d) & 0.5358 & 0.7993 \\
\hline
\end{tabular}


Table 3 Variation in release of volatile aldehydes, lipoxygenase II, and hydroperoxide lyase activity among 33 soybean genotypes before and after 12 months of storage

\begin{tabular}{|c|c|c|c|c|c|c|c|}
\hline \multirow[t]{2}{*}{ S. No. } & \multirow[t]{2}{*}{ Genotypes } & \multicolumn{2}{|c|}{$\begin{array}{l}\text { Volatile aldehydes } \\
\text { ( } \mu \mathrm{g} \mathrm{HCHO} / \mathrm{g} \text { seed) }\end{array}$} & \multicolumn{2}{|l|}{$\begin{array}{l}\text { Lipoxygenase II } \\
\text { (U/min/g seed) }\end{array}$} & \multicolumn{2}{|c|}{$\begin{array}{l}\text { Hydroperoxide lyase ( } \mu \text { mol NADH } \\
\text { oxidized/min/g seed) }\end{array}$} \\
\hline & & Before storage & After storage & Before storage & After storage & Before storage & After storage \\
\hline & Good storers & & & & & & \\
\hline 1 & AMSS-34 & 0.55 & 1.58 & 213.8 & 357.7 & 296.0 & 193.0 \\
\hline 2 & DS-74 & 0.54 & 1.41 & 412.2 & 424.2 & 546.0 & 230.0 \\
\hline 3 & DS-MM-64 & 0.41 & 1.44 & 241.1 & 258.0 & 423.0 & 135.0 \\
\hline 4 & G-2253 & 0.91 & 1.15 & 247.7 & 269.2 & 431.0 & 374.0 \\
\hline 5 & G-2265 & 0.60 & 1.18 & 238.9 & 307.7 & 410.0 & 391.0 \\
\hline 6 & G-2601 & 0.86 & 1.52 & 259.9 & 282.1 & 445.0 & 405.0 \\
\hline 7 & G-2603 & 0.66 & 1.65 & 207.3 & 224.2 & 447.0 & 351.0 \\
\hline 8 & G-2614 & 0.43 & 1.76 & 274.7 & 315.2 & 489.0 & 384.0 \\
\hline 9 & G-2651 & 0.45 & 0.86 & 261.9 & 266.4 & 418.0 & 449.0 \\
\hline 10 & M-253 & 0.69 & 1.62 & 130.1 & 283.4 & 307.0 & 421.0 \\
\hline 11 & M-1090 & 0.72 & 1.72 & 120.2 & 227.5 & 517.0 & 386.0 \\
\hline 12 & M-11913 & 1.02 & 1.19 & 130.8 & 220.1 & 404.0 & 360.0 \\
\hline 13 & TGX 444-422 & 0.52 & 1.01 & 232.8 & 245.9 & 348.0 & 318.0 \\
\hline \multirow[t]{3}{*}{14} & P-761 & 0.78 & 1.02 & 197.6 & 260.0 & 159.0 & 411.0 \\
\hline & Mean & 0.65 & 1.37 & 226.3 & 281.5 & 402.9 & 343.4 \\
\hline & Poor storers & & & & & & \\
\hline 15 & P-218 & 0.77 & 2.43 & 356.6 & 543.3 & 259.0 & 520.0 \\
\hline 16 & P-222 & 0.69 & 2.49 & 204.1 & 488.9 & 314.0 & 420.0 \\
\hline 17 & P-241 & 0.99 & 1.95 & 332.9 & 426.0 & 250.0 & 404.0 \\
\hline 18 & P-250 & 1.07 & 12.54 & 212.7 & 413.6 & 283.0 & 395.0 \\
\hline 19 & P-732 & 1.04 & 4.08 & 264.1 & 395.9 & 254.0 & 427.0 \\
\hline 20 & P-871 & 1.28 & 8.14 & 225.1 & 347.0 & 271.0 & 687.0 \\
\hline 21 & P-876 & 1.20 & 4.12 & 453.8 & 500.8 & 306.0 & 395.0 \\
\hline 22 & P-884 & 0.97 & 10.61 & 374.7 & 549.1 & 489.0 & 761.0 \\
\hline 23 & P-898 & 1.12 & 2.57 & 255.7 & 413.0 & 416.0 & 408.0 \\
\hline 24 & PK-262 & 0.73 & 8.29 & 513.4 & 810.7 & 575.0 & 827.0 \\
\hline 25 & PK-416 & 0.83 & 9.75 & 395.7 & 734.0 & 694.0 & 491.0 \\
\hline 26 & PK-472 & 1.49 & 10.68 & 577.6 & 967.5 & 1010.0 & 467.0 \\
\hline 27 & TAMS-38 & 1.27 & 7.77 & 217.9 & 392.4 & 568.0 & 424.0 \\
\hline 28 & EC-13969 & 0.65 & 8.70 & 213.4 & 411.4 & 344.0 & 379.0 \\
\hline 29 & EC-1023 & 1.05 & 4.72 & 187.2 & 497.1 & 401.0 & 307.0 \\
\hline 30 & EC-34141 & 0.77 & 3.98 & 206.3 & 663.1 & 379.0 & 321.0 \\
\hline 31 & EC-93751 & 0.82 & 3.80 & 252.8 & 552.8 & 301.0 & 224.0 \\
\hline 32 & EC-18761 & 0.70 & 9.76 & 265.1 & 452.2 & 248.0 & 313.0 \\
\hline \multirow[t]{4}{*}{33} & MACS-681 & 0.92 & 3.82 & 306.4 & 409.4 & 325.0 & 429.0 \\
\hline & Mean & 0.97 & 6.33 & 306.0 & 524.6 & 404.6 & 452.6 \\
\hline & MSD at $5 \%$ & 0.0915 & 0.2521 & 181.6 & 93.49 & 191.0 & 201.0 \\
\hline & SE (d) & 0.1371 & 0.2275 & 56.02 & 28.83 & 58.90 & 62.00 \\
\hline
\end{tabular}

compared to poor-storer genotypes $29.86(\mu \mathrm{S} / \mathrm{cm} / \mathrm{g}$ seed $)$ (Table 2).

An increase in electrolyte leakage from seeds was associated with a decrease in germination, with the change being more pronounced in large seeds [19]. Physical injury to seed coat and seed size are reported to adversely affect the electrical conductivity test results [13]. In the present study also, good-storer genotypes with lower electrolyte leakage were characterized by smaller seed size, black testa color, and better germination, as compared to poor-storer genotypes, which recorded higher electrolyte leakage, larger seed size, and yellow testa color. 
Table 4 Variation in antioxidant enzymes activity among 33 soybean genotypes before and after 12 months of storage

\begin{tabular}{|c|c|c|c|c|c|c|c|}
\hline \multirow[t]{2}{*}{ S. No. } & \multirow[t]{2}{*}{ Genotypes } & \multicolumn{2}{|c|}{$\begin{array}{l}\text { Superoxide dismutase } \\
\text { (U/min/g seed) }\end{array}$} & \multicolumn{2}{|c|}{$\begin{array}{l}\text { Glutathione reductase }(\mu \mathrm{mol} \\
\mathrm{NADPH} / \mathrm{min} / \mathrm{g} \text { seed) }\end{array}$} & \multicolumn{2}{|c|}{$\begin{array}{l}\text { Catalase }\left(\mu \mathrm{mol} \mathrm{H}_{2} \mathrm{O}_{2} / \mathrm{min} / \mathrm{g}\right. \\
\text { seed) }\end{array}$} \\
\hline & & Before storage & After storage & Before storage & After storage & Before storage & After storage \\
\hline & Good storers & & & & & & \\
\hline 1 & AMSS-34 & 8.6 & 9.7 & 1.7 & 2.4 & 286.5 & 296.5 \\
\hline 2 & DS-74 & 8.6 & 9.5 & 1.7 & 2.3 & 189.4 & 348.1 \\
\hline 3 & DS-MM-64 & 8.9 & 9.5 & 1.3 & 1.8 & 274.9 & 346.8 \\
\hline 4 & G-2253 & 9.0 & 9.6 & 1.7 & 2.6 & 157.8 & 276.5 \\
\hline 5 & G-2265 & 6.1 & 7.8 & 1.2 & 2.0 & 183.1 & 293.6 \\
\hline 6 & G-2601 & 7.7 & 9.3 & 1.1 & 1.8 & 259.2 & 391.0 \\
\hline 7 & G-2603 & 4.3 & 8.6 & 1.9 & 2.1 & 179.2 & 293.9 \\
\hline 8 & G-2614 & 8.2 & 9.4 & 1.5 & 1.7 & 95.52 & 365.2 \\
\hline 9 & G-2651 & 8.5 & 9.5 & 1.8 & 2.1 & 127.1 & 300.2 \\
\hline 10 & M-253 & 6.8 & 8.5 & 1.7 & 2.1 & 154.9 & 235.2 \\
\hline 11 & M-1090 & 6.2 & 6.3 & 1.7 & 2.1 & 179.2 & 228.4 \\
\hline 12 & M-11913 & 5.7 & 6.0 & 1.7 & 2.0 & 199.7 & 268.1 \\
\hline 13 & TG X 444-422 & 8.8 & 9.5 & 1.7 & 1.9 & 120.7 & 239.9 \\
\hline \multirow[t]{3}{*}{14} & P-761 & 8.8 & 8.9 & 2.9 & 3.0 & 118.4 & 174.2 \\
\hline & Mean & 7.6 & 8.7 & 1.7 & 2.1 & 180.4 & 289.8 \\
\hline & Poor storers & & & & & & \\
\hline 15 & P-218 & 9.1 & 4.0 & 2.3 & 1.9 & 1105.2 & 63.42 \\
\hline 16 & P-222 & 9.4 & 3.3 & 6.3 & 1.9 & 2054.2 & 168.1 \\
\hline 17 & P-241 & 9.2 & 2.5 & 4.0 & 1.2 & 1708.4 & 428.1 \\
\hline 18 & P-250 & 9.7 & 6.6 & 9.2 & 3.4 & 1304.2 & 210.5 \\
\hline 19 & P-732 & 9.3 & 6.3 & 2.3 & 1.4 & 1717.0 & 513.9 \\
\hline 20 & P-871 & 7.8 & 5.7 & 3.0 & 1.7 & 624.7 & 205.5 \\
\hline 21 & P-876 & 9.5 & 6.1 & 2.7 & 1.6 & 817.3 & 183.6 \\
\hline 22 & P-884 & 8.4 & 4.6 & 2.7 & 1.2 & 605.7 & 171.8 \\
\hline 23 & P-898 & 8.1 & 6.3 & 3.9 & 1.8 & 619.2 & 206.3 \\
\hline 24 & PK-262 & 7.8 & 6.1 & 8.0 & 1.6 & 892.8 & 172.8 \\
\hline 25 & PK-416 & 9.6 & 5.9 & 2.8 & 1.6 & 668.1 & 241.0 \\
\hline 26 & PK-472 & 9.4 & 4.7 & 9.3 & 3.0 & 932.3 & 175.5 \\
\hline 27 & TAMS-38 & 9.3 & 5.7 & 2.2 & 1.3 & 852.6 & 150.7 \\
\hline 28 & EC-13969 & 7.2 & 5.6 & 2.7 & 1.9 & 420.7 & 213.6 \\
\hline 29 & EC-1023 & 9.0 & 6.0 & 1.6 & 1.0 & 359.4 & 269.2 \\
\hline 30 & EC-34141 & 6.0 & 3.4 & 10.1 & 3.4 & 276.5 & 162.3 \\
\hline 31 & EC-93751 & 7.3 & 6.0 & 3.0 & 1.9 & 334.2 & 209.2 \\
\hline 32 & EC-18761 & 8.2 & 5.1 & 5.6 & 1.5 & 652.3 & 412.8 \\
\hline \multirow[t]{4}{*}{33} & MACS-681 & 9.7 & 8.3 & 2.5 & 1.2 & 652.8 & 183.6 \\
\hline & Mean & 8.6 & 5.4 & 4.4 & 1.8 & 873.5 & 228.5 \\
\hline & MSD at $5 \%$ & 0.9272 & 0.4057 & 1.594 & 0.5982 & 134.9 & 53.6 \\
\hline & SE (d) & 0.4342 & 0.2872 & 0.5695 & 0.3488 & 5.240 & 3.301 \\
\hline
\end{tabular}

\section{Lipid Peroxidation}

Peroxidation of membrane phospholipids, rich in unsaturated fatty acids, results in the production of hydroperoxides, which upon hydration are enzymatically metabolized to various aldehydes and ketones. These are highly reactive and have potential to attack macromolecules within the cell. The aldehydes and ketones released from hydrated seeds were trapped in MBTH solution and quantified colorimetrically. Significant variations were recorded in the 
release of volatile aldehydes from seeds of freshly harvested and ambient stored seeds. There were significant differences between the good and poor genotypes before and after storage (Table 3). In case of freshly harvested seeds, the average release of volatile aldehydes from the good-storer genotypes was $0.6521 \mu \mathrm{g} / \mathrm{g}$ seed, as compared to $0.9664 \mu \mathrm{g} / \mathrm{g}$ seed from poor-storer genotypes. After ambient storage, though the level of volatiles increased substantially, it was significantly lower in good-storer genotypes $(1.365 \mu \mathrm{g} / \mathrm{g}$ seed) than the poor-storer genotypes $(6.325 \mu \mathrm{g} / \mathrm{g}$ seed).

Peroxidation of fatty acids is the major cause of seed deterioration, which may occur both non-enzymatically (free radical mediated) and enzymatically (lipoxygenase catalyzed). Membrane phospholipids, rich in PUFA, are vulnerable to lipoxygenase activity, which results in deterioration of cell membrane. Among 33 genotypes, significantly higher LOX II mean activity (306.0 and 524.6 $\mathrm{U} / \mathrm{min} / \mathrm{g}$ seed) was noted in poor-storer genotypes as compared to (226.3 and $281.5 \mathrm{U} / \mathrm{min} / \mathrm{g}$ seed) good-storer genotypes in both freshly harvested and stored seeds, respectively (Table 3).

Hydroperoxide lyase (HPL) is an enzyme involved in lipid metabolism that cleaves hydroperoxides of certain PUFAs [18] into aldehydes. Among 33 genotypes, no significant difference was noted in the mean HPL activity of good- and poor-storer genotypes (Table 3). However, lower mean activity of hydroperoxide lyase $(343.4 \mu \mathrm{mol} /$ $\mathrm{min} / \mathrm{g}$ seed) was observed in good-storer genotypes, after ambient storage, as compared to poor-storer genotypes (452.6 $\mu \mathrm{mol} / \mathrm{min} / \mathrm{g}$ seed).

Accumulation of volatile aldehydes during seed ageing, which are released upon hydration, is an indicator of lipid peroxidation [21]. The level of volatile aldehydes released by the poor-storer genotypes was higher than good-storer genotypes, though it increased in all the genotypes during ageing (Table 3). This clearly indicated the role of lipid peroxidation in seed longevity behavior. In the present study, a sharp increase in the release of volatile aldehydes, concomitant with the reduction in germination under ambient conditions of storage, confirmed the above postulation $\left(r=-0.6638^{* *}\right)$. High activity of LOX I, LOX II and production of malondialdehyde and other volatile aldehydes were also reliable indicators of vigor, the levels being higher in the bold and yellow-seeded poor-storer varieties than the black and small seeded good-storer varieties as observed by Ashok Kumar [3]. From the present study, it was also evident that significantly higher LOX II mean activity was noted in poor-storer genotypes as compared to good-storer genotypes in both freshly harvested and stored seeds. A sharp increase in the lipoxygenase activity, concomitant with the reduction in germination under ambient conditions of storage indicated the role of lipid peroxidation in seed longevity behavior $\left(r=-0.7639^{* *}\right)$. From the present study, it is revealed that maintenance of high hydroperoxide lyase activity during storage resulted in higher release of volatile aldehydes and poor storability of seeds.

\section{Antioxidant Enzymes}

Superoxide dismutase (SOD) is first in the series of antioxidant system, which mollifies the superoxide radicals $\left(\mathrm{O}^{\bullet}\right)$, produced during electron transport process, into $\mathrm{H}_{2} \mathrm{O}_{2}$ and oxygen. It plays an important role in the process of free radical reaction and in seed ageing. Among 33 genotypes, freshly harvested seeds of poor-storer genotypes recorded higher SOD activity $(8.629 \mathrm{U} / \mathrm{min} / \mathrm{g}$ seed $)$ as compared to good-storer genotypes $(7.579 \mathrm{U} / \mathrm{min} / \mathrm{g}$ seed $)$. With the progress of the storage period, SOD activity significantly increased in good-storer genotypes $(8.716 \mathrm{U} / \mathrm{min} / \mathrm{g}$ seed $)$ and decreased drastically in poor-storer genotypes (5.387 $\mathrm{U} / \mathrm{min} / \mathrm{g}$ seed) (Table 4).

Enzyme glutathione reductase (GR) takes part in the control of endogenous hydrogen peroxide through an oxidoreduction cycle involving glutathione and ascorbate. In freshly harvested seeds of 33 genotypes, the poor storers recorded significantly higher GR activity $(4.424 \mu \mathrm{mol} / \mathrm{min} / \mathrm{g}$ seed) as compared to good-storer genotypes $(1.681 \mu \mathrm{mol} /$ $\mathrm{min} / \mathrm{g}$ seed). As the storage period progressed, GR activity increased significantly in good-storer genotypes $(2.134 \mu \mathrm{mol} / \mathrm{min} / \mathrm{g}$ seed $)$ on one hand and decreased significantly in poor-storer genotypes $(1.807 \mu \mathrm{mol} / \mathrm{min} / \mathrm{g}$ seed $)$ (Table 4).

Catalase (CAT) enzyme is essential for the removal of the potentially toxic $\mathrm{H}_{2} \mathrm{O}_{2}$ produced under various stress conditions and hence, for the avoidance of oxidative-stressrelated damage, by breaking hydrogen peroxide molecules to oxygen and water. It is located mainly in glyoxysomes. CAT is an important component of a plant's defense system. Similar to GR, the freshly harvested seeds of poor-storer genotypes recorded higher CAT activity $(873.5 \mu \mathrm{mol} / \mathrm{min} / \mathrm{g}$ seed) as compared to good-storer genotypes $(180.4 \mu \mathrm{mol} / \mathrm{min} / \mathrm{g}$ seed) (Table 4$)$. With the advancement of storage period, CAT activity significantly increased in good-storer genotypes $(289.8 \mu \mathrm{mol} / \mathrm{min} / \mathrm{g}$ seed) and decreased drastically in poor-storer genotypes (228.5 $\mu \mathrm{mol} / \mathrm{min} / \mathrm{g}$ seed).

Loss of seed viability has been reported to be associated with a reduction in the activities of antioxidant enzymes viz., SOD, CAT, and GR, which play a significant role in providing protection against highly reactive free radicals both under accelerated ageing and storage conditions $[4,10]$. Good storers were also characterized by tightly attached and thicker seed coat [Jagadish Hosamani et al. unpublished data] and a more efficient system of these 
radical scavenging enzymes. Thus, the present study confirmed the role of antioxidant enzymes in determining the storage behavior of soybean genotypes under ambient conditions. Though the poor-storer genotypes initially recorded higher enzyme activity (which may be due to an inherent response to a high influx of free radicals), it could not be sustained during storage, thus resulting in loss of viability. The good-storer genotypes, on the contrary, recorded more effective maintenance of seed viability owing to their superior antioxidant defense mechanism, which prevailed throughout the storage period.

\section{Conclusions}

A comprehensive assessment of the biochemical parameters revealed the critical role of hydroperoxide lyase and antioxidant enzymes in regulating the metabolic processes associated with seed storability. It is proposed that for breeding soybean varieties with better seed storability, screening for high efficiency of antioxidant enzymes, and down regulation of hydroperoxide lyase in seeds would serve as a more effective criteria, as compared to black/ thick testa or small seed size, which are not desirable agronomic traits.

Acknowledgments The first author is thankful to the Indian Council of Agricultural Research (ICAR), New Delhi, India, for the Grant of Senior Research Fellowship (SRF) during the $\mathrm{PhD}$ programme.

\section{References}

1. Aebi H (1984) Catalase in vitro. Method Enzymol 105:121-126

2. Agrawal PK, Dadlani M (eds) (1992) Techniques in Seed Science and Technology. South Asian Publisher, New Delhi 114-120

3. Ashok Kumar (2005) MSc Thesis Studies on storability and vigour parameters in soybean. Division of Seed Science and Technology, IARI, New Delhi

4. Bailly C, Benamar A, Corbineau F, Come D (1996) Changes in malondialdehyde content and in superoxide dismutase, catalase and glutathione reductase activities in sunflower seeds as related to deterioration during accelerated ageing. Physiol Planta 97:104-110

5. Beauchamp C, Fridovich I (1971) Superoxide dismutase: improved assays and an assay applicable to acrylamide gels. Anal Biochem 44:276-287

6. Bhatia VS (1996) Seed longevity as affected by field weathering and its association with seed coat and pod characters in soybean. Seed Res 24:82-87

7. Grossman S, Zakut R (1979) Determination of the activity of lipoxygenase (lipoxidase). Methods Biochem Anal 25:303-329

8. Hepburn HA, Powell AA, Matthews S (1984) Problems associated with the routine application of electrical conductivity measurements of individual seeds in the germination testing of peas and soybeans. Seed Sci Tech 12:403-413

9. ISTA (2008) International seed testing rules 2008 published by International Seed Testing Association, Zurich, Switzerland

10. Kuchlan MK (2006) PhD Thesis. Identification of physical, physiological and biochemical factors and molecular analysis for longevity of soybean seeds. Division of Seed Science and Technology, IARI, New Delhi

11. Kueneman EA, Wein HC (1981) Improving soybean stand establishment in the tropics by varietal selection for superior seed quality. IITA Res Brief 2(2):1-4

12. Kuo WHJ (1989) Delayed-permeability of soybean seed: characteristic and screening methodology. Seed Sci Tech 13:322-325

13. Loeffler TM, Tekrony DM, Egli DB (1988) The bulk conductivity test as an indicator of soybean seed quality. J Seed Tech $12: 37-53$

14. Marwanto Marlin, dan Mulya Marlinda (2003) The relationship between seed coat lignin content and seed quality of soybeans during storage. J Ilmu-Ilmu Pertanian Indonesia 5(1):12-17

15. Mavis RD, Stellwagen E (1968) Purification and subunit structure of glutathione reductase from baker's yeast. J Biol Chem 243: 809-814

16. Pandey R (1994) PhD Thesis. Changes in lipids and proteins during seed deterioration in soybean cultivars. Division of Plant Physiology, IARI, New Delhi

17. Priestley DA (1986) Seed ageing: implications for seed storage and persistence in the soil. Cornell University Press, Ithaca ISBN 0-8014-1865-8

18. Vick BA (1991) A spectrophotometric assay for hydroperoxide lyase. Lipids 26:317-322

19. Vyas RP, Kumar R, Prakash V, Katiyar RP (1990) Germinability of soybean seeds after harvest in subsequent storage. Seed Res $18: 44-46$

20. Wilson DO, McDonald MB (1986) A convenient volatile aldehydes assay for measuring seed vigour. Seed Sci Tech 14:269-271

21. Zhang M, Lui Y, Tori I, Sasaki H, Esashi Y (1993) Evolution of volatile compounds by seeds during storage periods. Seed Sci Tech 21:359-373 